\title{
MASSIMO DONÀ, Il pozzo infinito del niente. Da Lewis Carroll a Honoré de Balzac
}

\section{Marco Stupazzoni}

\section{(2) OpenEdition}

\section{Journals}

\section{Edizione digitale}

URL: http://journals.openedition.org/studifrancesi/16515

DOI: 10.4000/studifrancesi. 16515

ISSN: 2421-5856

\section{Editore}

Rosenberg \& Sellier

\section{Edizione cartacea}

Data di pubblicazione: 1 juillet 2019

Paginazione: 174

ISSN: 0039-2944

\section{Notizia bibliografica digitale}

Marco Stupazzoni, «massimo donà, Il pozzo infinito del niente. Da Lewis Carroll a Honoré de Balzac», Studi Francesi [Online], 187 (LXIII | I) | 2019, online dal 01 juillet 2019, consultato il 25 janvier 2021. URL: http://journals.openedition.org/studifrancesi/16515; DOI: https://doi.org/10.4000/studifrancesi. 16515

Questo documento è stato generato automaticamente il 25 janvier 2021.

\section{(c) (i) (9)}

Studi Francesi è distribuita con Licenza Creative Commons Attribuzione - Non commerciale - Non opere derivate 4.0 Internazionale. 


\title{
MASSIMO DONÀ, Il pozzo infinito del niente. Da Lewis Carroll a Honoré de Balzac
}

\author{
Marco Stupazzoni
}

\section{NOTIZIA}

MASSIMO DONÀ, Il pozzo infinito del niente. Da Lewis Carroll a Honoré de Balzac, in Di un'ingannevole bellezza. Le «cose» dell'arte, Milano, I Grandi Tascabili Bompiani, 2017, pp. 87-124.

1 Come nell'universo disincantato e «alla rovescia» dell'Alice di Lewis Carroll, la ricerca che Frenhofer compie nel Chef-d'oeuvre inconnu di Balzac per dare forma a quella unità originaria dell'arte che, oltrepassando i confini illusori del reale, si liberi dalla volontà di trovare un proprio stile e una propria tecnica particolari, è votata al fallimento in quanto destinata a risolversi nella semplice negazione «del distinguersi dei distinti» (p. 105). Nell'opera d'arte, Frenhofer ricerca l'anima, vale a dire la sola dimensione in grado di svelare la bellezza realizzando la sua perfetta unità: ma questo presuppone il superamento degli inganni del sensibile, ossia della forma «molteplice e diveniente che caratterizza le sue intrascendibili, ma insieme infinite, possibilità espressive» (p. 111). Per raggiungere quel fine, cioè superare le forme ingannevoli del reale, Frenhofer, al termine del suo estenuante percorso di ricerca, non sperimenta altro che il nulla assoluto, ossia la fine dell'arte. In altri termini, Frenhofer «non avrebbe potuto dir nulla di "diverso" dal mondo di cui pur avesse voluto sancire la più radicale "negazione"» (ibid.). 